\title{
Moradas, viajes, lecciones: cronotopo e intensidad en el "novísimo" cine chileno"
}

\author{
Dwellings, Travels, Lessons: Chronotope \\ and Intensity in the "Newest" Chilean Cinema
}

\author{
Ignacio Albornoz Fariña \\ Paris VIII Vincennes-Saint-Denis \\ ignacio.n.albornoz@gmail.com
}

\section{Resumen}

Este artículo expone algunas actualizaciones del cronotopo bajtiniano del camino en tres filmes del "novísimo cine chileno". En primer lugar, se estudiarán las modalidades viajeras que las tres obras proponen, gracias a nociones de la filosofía y la teoría del turismo. ${ }^{2} \mathrm{Se}$ identificará, luego, una serie de submotivos cronotópicos, verdaderos momentos afectivos, que desembocarán en nuestra hipótesis de trabajo; a saber, que las protagonistas de cada filme recorren un "espacio liso", genérico, hecho de intensidades, un "medio" donde lo que prima es la "experiencia", el aprendizaje y el encuentro con sí mismas.

Palabras clave: Novísimo cine chileno, viaje, intensidad, relato de aprendizaje, cronotopo del camino.

\section{Abstract}

This article exposes some actualizations of the bakhtinian chronotope of the road in three films of the "young Chilean cinema". It will start by analyzing the different travelling modalities proposed by these works, based on some notions from contemporary philosophy and tourism studies. It will then identify a discrete series of chronotopical sub-motifs, authentic affective moments, that will lead to a working hypothesis, namely: the characters of the studied films move through a "smooth", generic space, one of intensities, a milieu where what is primed is "experience", personal growth and self-discovery.

Keywords: Newest Chilean cinema, travel, intensity, coming-of-age film, chronotope of the road.

1 Algunas de las conclusiones del presente trabajo provienen de una tesis de magíster dirigida por Christa Blümlinger en la Universidad Paris viII Vincennes-Saint-Denis, y financiada por el programa Becas Chile de conicyt.

2 Una buena parte de las citaciones contenidas en este artículo provienen de libros o artículos publicados originalmente en inglés o francés, y para los cuales no existe aún traducción en español. Con el objetivo de facilitar la lectura y no interrumpir el ritmo del texto, hemos preferido, pues, presentarlas en su versión castellana, que hemos traducido oportunamente. 


\section{Introducción}

Durante la secuencia inicial de El árbol magnético (2013), de Isabel Ayguavives, la cámara se detiene algunos instantes frente a una señalética campestre y pintoresca en la que puede leerse: "Señor turista: usted se encuentra en una zona magnética". El plano forma parte de una serie de imágenes introductorias que exponen el pacífico paisaje del Valle Central de Chile: montañas monumentales, flores y arbustos que ondulan plácidamente al viento, detalles de una adorable cabaña de vacaciones. Texto e imagen componen, en el devenir de esta secuencia de apertura, un cuadro que representa una de las tantas líneas recientes del cine nacional de ficción: a saber, la de un conjunto de filmes que circulan en torno a historias íntimas y familiares vividas por personajes que, según la fórmula utilizada por la crítica, parecen estar continuamente "en tránsito" (Urrutia, "Hacia una política” 38; Donoso 139; Valenzuela Prado 142; Depetris 19).

Desarraigados, alienados o víctimas lisa y llanamente del más mortal de los tedios, estos personajes buscan de manera voluntaria el aislamiento y la inmersión en la naturaleza, en los que cifran la posibilidad de una reconversión, de un cambio trascendente o, simplemente, de un redescubrimiento de sí mismos. Las diferentes formas de movilidad que sus itinerarios describen se asemejan así, con frecuencia, a las dinámicas de los filmes europeos o americanos de coming-of-age, a las de las road-movies y, aunque en grado menor, a las del Bildungsroman. Se trata, en cualquier caso, de relatos en los que el viaje, y especialmente "el desplazamiento por ámbitos rurales" (Díaz-Zambrana 58), es comprendido como una práctica social que vehicula una necesaria "inclinación del individuo a salir de su cuadro de vida habitual (traducido por el autor)" (Amirou 13). Ciertas herramientas analíticas de la literatura, la filosofía y otras disciplinas pueden ayudarnos a comprender con mayor precisión sus modalidades, que hemos decidido situar aquí bajo el signo de la "intensidad".

\section{Antecedentes críticos del "novísimo" cine chileno}

La crítica nacional consigna, en el cine, un giro fundamental, operado aparentemente en los albores del nuevo milenio. Se trataría de un nuevo paradigma estético cuya fecha de inicio sería por toda seña - investigadores y comentaristas no polemizan mucho al respecto- el año 2005. La literatura especializada nos ofrece, desde luego,

3 Dos obras de aparición más o menos reciente han quedado, por razones tocantes a los siempre mudables calendarios de publicación, al margen del corpus bibliográfico de este artículo: Tierras en trance: arte y naturaleza después del paisaje, de Jens Andermann, y Chilean Cinema in the Twenty-First-Century World, volumen colectivo editado en 2020 por Vania Barraza y Carl Fischer. Aunque altamente pertinentes y relevantes, el estado ya avanzado del presente escrito no me permitía dialogar adecuadamente con ellas sin modificaciones mayores de la estructura y sentido del texto. No obstante, el lector queda calurosamente invitado a consultarlas en detalle y a descubrir posibles nexos o divergencias. 
distintas maneras de nombrarlo. Un hito temprano a este respecto es, sin duda, la publicación de El novísimo cine chileno de Ascanio Cavallo y Gonzalo Maza quienes, en 2010, creyeron circunscribirlo mediante una fórmula deliberadamente hiperbólica que designaba un cine ajeno a los circuitos comerciales y preocupado sobre todo por "defender su autonomía creativa" (14). Desde entonces, y aunque espoleadas en parte por esta iniciativa fundadora, la crítica, en sus vertientes académica y periodística, ha intentado ceñir el fenómeno por medio de diversas nomenclaturas, con grados variables de adherencia, y teniendo siempre "como principales ejes de conflicto [...] la intimidad y su vínculo con la política" (Parra) o, en términos de Iván Pinto, "la querella difusa entre su politización y su despolitización" (Pinto, "Materialismos" 137).

Allí donde Pablo Corro ha creído ver, por ejemplo, vía Gianni Vattimo, el surgimiento de "poéticas débiles" interesadas por "argumentos de menudencias, de asuntos insignificantes" (Corro 217), Antonella Estévez ha preferido reconocer el sello de "lo melancólico" y del no-duelo, haciendo referencia a aspectos tanto técnicos (fijeza o estabilidad de los planos, duración de las secuencias, suspensión del montaje) y argumentales (intrigas simples o mínimas, presencia de pocos personajes) como ideológicos (interpelación al espectador, demanda de visualización activa). Por su parte, Carlos Saavedra, en clave más crítica, ha leído la preferencia de este cine joven por "los recorridos y aventuras mínimas de individuos encerrados en espacios privados" como una "proyección simbólica de la sociedad chilena reciente: claustrofóbica, excluyente y temerosa" (Una gramática 15), lo que lo ha conducido a postular los contornos de un cine de "intimidades desencantadas" que reconocería "al individuo como la única 'existencia social' capaz de articular un discurso" (26). De manera similar, Salinas y Stange diagnostican, en las corrientes más intimistas del novísimo cine, cuya "búsqueda de nuevas formas" (232) dejaría entrever a fin de cuentas un carácter reaccionario, la ausencia de un discurso "disrruptor" o "crítico" (231), lo cual deploran.

Aunque atendibles, algunas de estas apreciaciones desconocen sin embargo que el novísimo no es en absoluto un bloque monolítico, como lo han demostrado ya Pinto, González y Munjin (Pinto, "Rupturas" 118; Pinto et al. 73), quienes han subrayado la existencia de una segunda y hasta tercera división dentro del cine nacional, representadas por películas que "se posicionan por fuera de las narrativas y estéticas predominantes durante la última década [...], tensionando una posible homogeneidad del canon actual" (Pinto et al. 72). Las marcas de esa diversidad, por lo demás, aparecían ya de manera bastante clara en el volumen iniciático de Cavallo y Maza, en el que se daban cita obras con presupuestos estético-ideológicos a veces contradictorios, como En la cama (2005) de Matías Bize y El pejesapo (2007) de José Luis Sepúlveda. En uno de los abordajes más recientes al tema, Vania Barraza ha inyectado felizmente ciertos matices al debate al entender el cine nacional como un paisaje de ramificaciones complejas en el que se observa "una confluencia entre estética, el síntoma del desapego de la postdictadura [...] y el comentario social” (13). 
Menos interesado por la definición del estatus político o "crítico" de las obras analizadas, y situándose al margen de aquellas lecturas alegóricas que ambicionan compensar la parquedad discursiva de los objetos con diagnósticos de corte memorial por lo menos audaces, el presente artículo prefiere adherir más bien, y de manera bastante literal, a la tesis de Carolina Urrutia, según la cual el giro en cuestión indicaría la génesis de un cine "centrífugo", caracterizado por el ejercicio de "nuevas trayectorias de los cuerpos, curvas de velocidades y lentitudes que definen, además de un rito específico, otras cartografías espaciales" (Un Cine 20). A esta reflexión viene a sumarse la de Andrea López, quien considera, en una línea similar, que estas nuevas dinámicas se manifestarían, sobre todo, en el tratamiento cada vez más ostensible de figuras que responden a una suerte de "condición nómade" y en la representación de personajes que "no tienen lugar de pertenencia ni un hogar al que retornar" (68). A este respecto, un barrido de la literatura existente permite constatar, entre otras características: una aparente despolitización del discurso (Salinas y Stange 220; Lie 7), marcada por un abandono de "[...] la necesidad de tratar de manera abiertamente política - o alegórica - los temas ligados a la dictadura y al retorno de la democracia” (López 3); una puesta en escena de temáticas cada vez más íntimas o subjetivas (Póo et al. 6; Saavedra 21; Kemp 205; Díaz-Zambrana 57); ${ }^{4}$ el establecimiento definitivo de nuevas tecnologías de grabación, de producción y de distribución (Urrutia, "Hacia una política" 36; Chamorro 222; Saavedra 63; Larraín 158); una relativa diversificación de los géneros cultivados (Larraín 161); una desaceleración considerable del ritmo narrativo y una nueva relevancia de objetos aparentemente insignificantes y pertenecientes a la esfera de lo cotidiano (Urrutia, "Hacia” 35; Estévez, "Dolores" 27; López 45).

El árbol magnético, De jueves a domingo y Raíz responden, como puede verse, a propensiones que parecen manifestarse con cierta regularidad en el cine chileno contemporáneo de ficción, sin ser por ello excluyentes. Por otro lado, las tres obras constituyen algo así como ejemplares aprobados de lo que, en Chile, se considera un cine de calidad o, por lo menos, de actualidad: las tres cintas han recibido, en distintas instancias, reconocimientos oficiales que las validan, siendo quizás El árbol magnético — que contó sin embargo con una gran circulación internacional- el menos exitoso de ellos. Raíz, por su parte, obtuvo en 2014 el gran premio del Festival Internacional de Cine de Valdivia. De jueves a domingo recibió un número considerable de galardones internacionales que lo convirtieron en uno de los filmes chilenos más premiados de los últimos años.

En cierto sentido, las tres cintas citadas son también ejemplos arquetípicos de un esquema temático que ganó cierta adhesión entre los y las cineastas del país y que tuvo en filmes como Bahía azul (Nicolás Acuña, 2012), Navidad (Sebastián Lelio, 2009), Paseo (Sergio Castro, 2009), Mamá (Juan Pablo Fernández, 2010), Mar (Dominga

4 Con respecto a este último punto, Carolina Urrutia, académica chilena, afirma: "hay un cambio de escala, el desplazamiento de un gran relato a uno individual y de escala humana, en profunda complicidad hacia el presente" (Un Cine 42). 
Sotomayor, 2014) y Weekend (Joaquín Mora, 2009) algunos representantes. Estas últimas cintas, junto con las que constituyen el núcleo de este artículo, podrían inscribirse, por cierto, dentro de lo que Deborah Martin denomina una "escena cinematográfica mundial", caracterizada por la prominencia de una estética de "sensaciones" que otorga a fenómenos como la lentitud y la contemplación una nueva relevancia ontológica (cit. en Randall 104). En ese mismo sentido podrían responder también al "giro afectivo" que la literatura, sobre todo en el ámbito anglosajón, diagnostica en buena parte de las producciones contemporáneas en Latinoamérica, lo que explicaría en parte la inédita visibilidad de subjetividades antes relegadas a los márgenes de la representación, como niños, adolescentes y personajes femeninos. ${ }^{5}$ Asimismo, las películas en cuestión parecieran participar en definitiva, y en razón del relativo "fracaso" (Díaz-Zambrana 65; Navarro-Daniels 195) de las formas "accidentadas" de movilidad que actualizan, en lo que Nadia Lie ha dado recientemente en llamar la counter-road-movie latinoamericana, género en el que el movimiento se vería reflejado paradójicamente a través de su reverso, vale decir a través de una cierta “inmovilidad” (Lie 15). Desde una perspectiva diacrónica, finalmente, estas cintas representan acaso, para el cine chileno, una reacción ante los ejercicios de errancia eminentemente urbanos que lo habían caracterizado durante los años 90 y 2000, y que tenían en cintas tan disímiles, aunque construidas siempre en torno a subjetividades masculinas (Pino-Ojeda 91), como Caluga o menta (1990), Taxi para 3 (2001) y El gringuito (1998) sus más célebres exponentes.

\section{Dime cómo viajas y te diré quién eres}

El viajero, escribe James Clifford, es "por definición, alguien que tiene la seguridad y el privilegio de moverse de maneras relativamente libres (unconstrained)" (107). "En todo caso", precisa enseguida, "este es el mito del viaje [traducido por el autor]" (107). A esta definición, deliberadamente problemática, podríamos añadir aquella, un tanto demodée, de Paul Fussel, quien distinguía tres formas de experiencia viajera, correspondientes respectivamente a los imaginarios del Renacimiento, del Romanticismo (era burguesa) y de la Modernidad (era proletaria): la del explorador, la del viajero y la del turista, modalidades entre las cuales, evidentemente, algunas superposiciones son posibles. No obstante, para Fussel el balance general es más bien negativo y representa una regresión. "Asumo", escribe, "que el viaje resulta hoy imposible y el turismo es todo lo que nos queda [traducido por el autor]" (41).

5 Varios volúmenes y artículos se han volcado durante los últimos años al estudio de los afectos, siempre en el marco de la emergencia de nuevas subjetividades. Además de los textos referenciados más abajo, cabría destacar, a este respecto, los libros The Politics of Affect and Emotion in Contemporary Latin American Cinema de Laura Podalsky, The Feeling Child: Affect and Politics in Latin American Literature and Film, de Philippa Page, Inela Selimović y Camila Sutherland y New Visions of Adolescence in Contemporary Latin American, de Geoffrey Maguire y Rachel Randall. 
En el mismo orden de ideas, la visión, de apariencia un tanto maniquea y esquemática, de Syed Manzurul Islam, quien establece una diferencia actualizada por la performance individual, entre viajeros "nómades" y "sedentarios", puede servir a iluminar un poco la cuestión que nos interesa. Aunque admite que "cada objeto de búsqueda define un viajero: [es decir que] hay tantos viajeros como hay objetos [traducido por el autor]" (55) y que, paralelamente, "existen tantas rutas como viajeros hay" (55), Islam se muestra intransigente a la hora de clasificar las experiencias viajeras, que evalúa según una oposición cualitativa irreductible cuya virtud consiste en desplazar la atención del tipo de movimiento realizado a la intensidad de su velocidad: "a pesar de la diversidad de las rutas, hay solo dos líneas de viaje: una rígida y una flexible. Estas establecen la diferencia cualitativa entre los viajeros: o se es un viajero sedentario o se es un viajero nómade" (55).

Conviene notar, de paso, que la categorización binaria de Islam proviene - es él mismo quien explicita la filiación - de los postulados de Deleuze y Guattari y, más tangencialmente - aunque sin el "exceso metafísico"-, de la filosofía de Heidegger y de su concepto de "hábitat" (wohnen). Como tal, sus términos constituyen tendencias virtuales que interactúan en un mismo plano de inmanencia (Islam 59) y no nociones mutualmente excluyentes. Entre ambas, en efecto, inversiones, contactos e intercambios son posibles. Lo que importa, al fin, en el sistema de Islam, es la comprensión del viaje como "devenir", como proceso siempre en curso; en fin, como continuum acaso irreductible cuya especificidad, en su vertiente "lisa", estaría dada más por la "intensidad" que por el movimiento factual de un cuerpo entre dos puntos: "se va a través de los puntos, y no de un punto hacia otro" (60). Pero también nos interesa subrayar —acabamos de decirlo - la identidad de esta noción con el concepto heideggeriano de "hábitat", entendido como un "modo de morar afundacional y transitorio que no se opone al viaje" (56), cuya relevancia nos parece vital para el análisis de los filmes estudiados.

Convendría añadir, finalmente, a estas consideraciones sobre el viaje, las que consigna Erik Cohen. El académico israelí establece una grilla fenomenológica que considera cinco modalidades turísticas que dependerían de la mayor o menor adherencia del sujeto viajero a un "centro" (180): "Fenomenológicamente, los distintos modos de experiencias turísticas están relacionados con los tipos de relaciones que se establecen entre una persona y una variedad de 'centros' [traducido por el autor]" (180). El concepto de "centro" - claro está- no es entendido aquí necesariamente como una entidad con coordenadas geográficas concretas, pues un centro puede también ser excéntrico y cifrar en su misma excentricidad toda su potencia sugestiva. En términos más amplios, el centro que Cohen intenta aprehender es individual y "espiritual"; se trata, al fin, para el autor, de un locus "que simboliza, para el individuo, los significados últimos” (181), en cuya búsqueda cada quien puede adoptar distintas actitudes, dependiendo de su nivel de alienación.

La modalidad que nos parece más adecuada en el marco de las cintas analizadas es la que Cohen denomina "experimental", en la cual el encuentro con un 
otro diametralmente opuesto ha sido evacuado, no por rechazo, animadversión o estrechez de espíritu. Se trata, simplemente, de un cambio de focalización, pues el "otro" que el turista experimental trata de encontrar y comprender es, en el fondo, él mismo. Cohen escribe:

El turista "experimental" se encuentra en una "búsqueda de sí mismo", en la medida en que, dentro de un proceso de ensayo y error, intenta descubrir aquella forma de vida que suscite en él una resonancia; no es realmente consciente de lo que busca, de sus necesidades "reales", de sus deseos. La suya es una búsqueda esencialmente religiosa, pero difusa y sin metas claras (189).

Lo que lo domina es, pues, en el imaginario del turista experimental, un sentimiento de alienación y la certeza de la necesidad de una partida inminente, aunque sin razones precisas: "alienado del centro espiritual de su propia sociedad, activamente, aunque tal vez de manera inarticulada, [el turista experimental] busca un nuevo 'significado"' (187). Se trata, en el fondo, y guardando toda proporción, de una reactualización del célebre y ya muy manido adagio que Michel de Montaigne inmortalizó en el tercer libro de sus Ensayos: "Por lo común respondo, a aquellos que me preguntan las razones de mis viajes, que sé bien de lo qué huyo, pero no qué busco" (68).

Por otro lado, esta modalidad implica una cierta apertura, un carácter irresoluto, no definitivo, que parece estar en perfecta armonía con los atributos que Islam, espoleado por Deleuze, Guattari y Heidegger, reconocía en el viajero "nómade", aquel que hace de su viaje por líneas "flexibles" una morada, en constante movimiento a través de los puntos del espacio que recorre, sin jamás llegar a ninguno de ellos: "En efecto, en casos extremos la búsqueda misma puede convertirse en un modo de vida, y el viajero en un sujeto en búsqueda eterna" (Cohen 189). Desde este punto de vista, los confines, las dimensiones en principio no mensurables del viaje constituyen también, a su modo, un espacio habitable, un amparo, un refugio. Y es que, como lo señala pertinentemente Gastón Bachelard, "todo espacio realmente habitado lleva como esencia la noción de casa, [...] [pues], en la más interminable de las dialécticas, el ser amparado sensibiliza los límites de su albergue. Vive la casa en su realidad y en su virtualidad, con el pensamiento y los sueños" (Poética 28).

Sería pertinente recordar, por último, una clasificación del campo de la literatura, propuesta por Macarena Areco. La autora nos sugiere pensar la narrativa chilena a partir de dos series que, de acuerdo a sus palabras, "escenifican imaginaciones espaciales opuestas" (253): la novela de la intimidad, preocupada por "los lugares cerrados y el mundo de la burguesía" y la de la intemperie, fascinada "con lo abierto y lo proletario”. El esquema, sin embargo, no se queda ahí. Como síntesis, Areco propone una categoría que resulta, a todas luces, significativa para los filmes que estudiamos: la de las novelas "de trayecto", que deconstruyen la antedicha oposición por intermedio de la representación de "tránsitos de diverso tipo: circulares, de regreso y de huidas, a veces emancipatorios, otras destructivos” (253). 


\section{Tres trayectos, tres vidas}

Para comprender más en detalle las experiencias de viaje de Marianela, Lucía y Amalia, las tres protagonistas de los filmes estudiados, conviene retener, a la luz de las constataciones anteriores, algunas características concretas de sus trayectos. Reconstituyamos en algunas líneas, para esto, las intrigas de cada película.

El árbol magnético, muy a la manera de L'Heure d'Été (2007) de Olivier Assayas o de Family Tour (2013) de Liliana Torres, registra un fin de semana en la vida de Marianela, joven de naturaleza introvertida y calma. La premisa que desata la acción es simple: Marianela y sus padres deben dirigirse a una vieja casa de vacaciones que la familia posee en el Valle Central del país. Toda la camada de tíos, nietos, sobrinos y primos que componen el clan familiar acude a la cita. Entre los asistentes, dos figuras sobresalen, sin embargo: la abuela, personaje lacónico y ascético, y Bruno, el primo español, de espíritu cosmopolita, quien se encuentra de paso por Latinoamérica. A través de alusiones cada vez más llanas, el guion nos advertirá que la médula del relato se encuentra en el lazo que une a los primos, cuya naturaleza no puede reducirse a la mera consanguineidad.

La razón de este encuentro multitudinario no se nos oculta tampoco: la casa de vacaciones va a ser vendida, pues nadie se ocupa ya de ella y las estadías son cada vez menos frecuentes. El único personaje que parece sin embargo resentir la venta es Marianela, quien enrostra constantemente a los demás su falta de sensibilidad ante la inminente destrucción de un lugar que guarda, en su memoria, los más entrañables recuerdos de la infancia, de un pasado cuya volatilización le resulta intolerable. El núcleo dramático del relato reside justamente ahí, en la incapacidad de la protagonista para vivir el duelo material y existencial de ese tiempo pretérito que incluye, ciertamente, sus momentos de pasión infantil junto a Bruno.

En De jueves a domingo, en cambio, los móviles del viaje son diferentes. El núcleo familiar, esta vez, es además menos numeroso. A grandes rasgos, el relato se focaliza en la figura de Lucía, una niña al borde de la adolescencia. El padre, Fernando, conduce a su hija e hijo, Lucía y Manuel, y a su mujer, Ana, en un viaje de tres días con el fin de mostrarles un pequeño terreno que ha adquirido recientemente en el norte del país, donde planea construir, más adelante, una gran casa de vacaciones. Este, no obstante, no es más que un pretexto que esconde la verdadera razón que motiva la escapada, la cual nos será revelada hacia el final del filme. En una de las últimas secuencias podemos ver en efecto una discusión entre Ana y Fernando, en la que este revela a su mujer que dejará la casa de Santiago, pues acaba de arrendar un apartamento de soltero. Esta revelación final reviste el viaje con una significación completamente distinta, nueva, y transforma un paseo hasta entonces un tanto anodino, de un golpe, en una experiencia mucho más crítica y trascendental: la de las últimas vacaciones en familia.

En Raíz, por último, el conflicto resulta evidente desde el inicio del relato, que comienza con una conversación telefónica aparentemente áspera y lacónica entre 
Amalia, una joven de 26 años, y su madre, que vive en Puerto Varas, ciudad del sur de Chile. El propósito de la llamada es poner al corriente a Amalia de la muerte de la antigua empleada doméstica de la familia, quien deja tras de sí un hijo huérfano, el pequeño Cristóbal, niño parco y solemne. Desde entonces comienza un viaje en el que Amalia, retomando en cierta medida un vínculo familiar que creía perdido, conduce a Cristóbal en la búsqueda de su padre, quien se encuentra relegado en un pueblo aledaño. Los trayectos se hacen generalmente en un religioso silencio, a bordo una vieja camioneta que señala sin equívocos, como gran parte de los objetos domésticos sobre los que la cámara se detiene, el paso del tiempo, el abandono. Como en De jueves a domingo, cada tanto, esos desplazamientos son sin embargo interrumpidos —o deberíamos decir, más bien, ritmados- por secuencias digresivas que suspenden el conflicto central y cuyo objetivo es ofrecer un refugio, un reposo, tanto a los engranajes del relato (el viaje, simbólicamente, se detiene) como a los cuerpos mismos de los protagonistas, que se abandonan a su vez, por unos minutos, a la inmovilidad (dejándose por ejemplo flotar a la deriva en un riachuelo o tomando, simplemente, una ducha).

\section{El cronotopo del camino: una respuesta figurativa al viaje como aprendizaje, paso y hábitat}

El cronotopo bajtiniano del camino constituye una herramienta analítica privilegiada para el estudio de las figuraciones fílmicas concretas del tema del viaje comprendido como instancia de aprendizaje, rito de paso y búsqueda de un hábitat, aunque sea este transitorio. La noción permite, en efecto, aislar una serie de submotivos genéricos que se inscriben, a su vez, en una tradición literaria de más largo aliento que los anima y les da espesor.

En el sistema de Bajtín, el cronotopo es una categoría literaria que expresa "el carácter indisoluble del espacio y el tiempo (237). Los cronotopos cumplen, dentro del contexto de cada relato, una función a la vez temática y estructural, pues, por un lado "son los centros organizadores de [sus] principales acontecimientos" (400) y, por el otro, generan su asunto o argumento (400). Pero hay aún un tercer aspecto esencial del cronotopo, ineludible: su función figurativa, que le permite condensar en sí lo más importante de cada narración. En palabras de Bajtín, “[t]odos los elementos abstractos de la novela - generalizaciones filosóficas y sociales, ideas, análisis de las causas y de los efectos, etc.- tienden hacia el cronotopo" (401). Los cronotopos pueden además, nos dice, descomponerse en motivos más elementales, a los que da el apelativo de "menores", entre los cuales pueden, a su vez, establecerse toda suerte de vínculos: "pueden incorporarse uno a otro, coexistir, combinarse, sucederse, compararse, confrontarse o encontrarse complejamente interrelacionados" (402-3). A pesar de esta dispersión, la mayor parte de las veces el analista logra organizar las 
relaciones espacio-temporales propuestas por los cronotopos menores alrededor de un cronotopo más general, "que abarca o domina más que los demás” (402).

Uno de estos cronotopos organizadores, reconocido por el mismo Bajtín, es el “del camino", de enorme importancia en la literatura. Entre las características principales de este cronotopo está la de marcar un paso a través de un territorio relativamente cercano al universo del protagonista: "el camino pasa por el país natal, conocido, en el que no existe nada exótico ni ajeno” (273). En otras palabras, el cronotopo del camino no implicaría extrañamiento. Pero el cronotopo del camino se caracteriza también por su naturaleza metafórica, indisimulable. Como representación de un trayecto que se desarrolla por etapas, el camino es en efecto índice de un recorrido vital o de una transformación que se opera en el interior de los personajes: "Puede afirmarse rotundamente", anota Bajtín, "que el camino no es nunca en el folclore simplemente un camino, sino que constituye siempre el camino de la vida o una parte de este; la elección del camino significa la elección del camino de la vida" (273).

Ahora bien, si el camino señala, por la estructura y los significados que les son propios, la presencia de una metáfora ineludible, su representación resulta, por lo mismo, indisociable de un espacio cuyos ecos alegóricos ya hemos sugerido. Nos referimos al hogar natal, presente en los tres filmes estudiados. Y es que, para marcharse, hay que haber dejado, antes que nada, ese lugar liminar, la casa, punto de partida obligado de todo relato de viaje. Este acto de abandono - Bajtín lo consigna - no es insignificante. $\mathrm{Al}$ contrario, representa una suerte de umbral que señala, por su sola presencia, un giro vital, el momento preciso en el que la posibilidad de un cambio se insinúa: "la salida de la casa natal al camino, y la vuelta a casa, constituyen generalmente las etapas de la edad de la vida (sale un joven, y vuelve un hombre)" (273).

En el marco de las obras analizadas, cada uno de los viajes marca en efecto el momento de un paso, de una transformación en cuyo éxito están cifradas las esperanzas de una maduración. Lo que parece operarse en las protagonistas al cabo de sus desplazamientos individuales es algo así como una cura, una regeneración que posee la virtud de renovar o modificar sus lazos con su mundo próximo, representado generalmente por la familia.

Urge decir, no obstante, que en estos relatos el encuentro con el "otro" - característico del cronotopo del camino- solo podrá ser abordado a través de un desdoblamiento personal, pues los universos representados no autorizan el cruce de clases sociales ni el acercamiento a "otros" ajenos al círculo familiar. Raíz, Jueves y El árbol capturan, en ese sentido, el instante de una confrontación a la vez física - concreta, real- y simbólica de las protagonistas consigo mismas. Amalia, Lucía y Marianela deben enfrentarse, por un lado, a su propio envejecimiento - serán efectivamente, y a pesar de la concisión del tiempo representado, más viejas al final del relato- y, por el otro, a la consecuencia de esa misma mengua: la maduración. Antes de esto, sin embargo, deben partir, pues la única condición que los relatos les imponen es que la transformación se efectúe, ineluctablemente, afuera, en ruta, lejos de casa. 
Pero no es exactamente en el camino que el cambio podrá tener lugar. Como lo advierte el propio Bajtín, es más bien en sus márgenes, en sus recodos y paradas - los stopping places del cine de los que habla Rob Lapsley- que tienen lugar los eventos fundamentales del relato. Cronotopo esencialmente "saturado", el camino se encuentra henchido por "un tiempo mucho más sustancial" (Bajtín 273), intenso, que otorga a los acontecimientos de lo que el mismo Bajtín llama "la vida corriente", situados por definición en los márgenes de la ruta y, como lo sugiriéramos ya con Lie, al interior de una dialéctica entre inmovilidad y movilidad, ${ }^{6}$ una profundidad inusitada. Esa profundidad hace de ellos, en palabras de Selimović, verdaderos "momentos afectivos", es decir "configuraciones materiales particulares" - "breves en duración aunque perdurables en su impacto" - en los que los "encuentros interpersonales centrales para la narración se espesan” (14-5) o se intensifican, siempre al margen del lenguaje. En otras palabras, podemos decir que el cronotopo del camino actúa, en las cintas analizadas, como un principio estructurador alrededor del cual gravitan todos los otros elementos del relato. Para ilustrar esta idea, proponemos aquí una serie discreta de submotivos (espacios de concreción de "momentos afectivos") que interactúan con el motivo "mayor" del camino, del cual retendremos, al menos, estos cinco trazos distintivos: a) su aspecto local, familiar; b) su dimensión (reflexiva) de encuentro con el "otro"; c) su naturaleza metafórica de "camino de vida", de aprendizaje, de crecimiento personal; d) su saturación o condensación temporal (vale decir, su intensidad); y e) su emplazamiento al interior, o más bien en el medio, de una dialéctica que boga entre movilidad e inmovilidad.

Con excepción del primero, cuyo despliegue se efectúa "pacientemente y por pinceladas [traducido por el autor]" (Thomas 148) —o, si se quiere, por acumulación-, todos estos submotivos trabajarán por lo general en la escala más discreta de un plano o de una secuencia precisos, concretizando o "haciendo sensible" a través de la imagen aquello que Benjamin Thomas, en una lectura erudita de Augustin Berque, ha dado en llamar "medio" ( milieu), término con el que designa la "génesis recíproca de un cuerpo y un espacio" (158), es decir, la posibilidad verlos "al mismo tiempo, plenamente, en su entrelazamiento constitutivo" (76).

\section{La casa, motor y destino}

"A veces", escribe Gastón Bachelard, "la casa del porvenir es más sólida, más clara, más vasta que todas las casas del pasado” (Poética 70). En los filmes que estudiamos, las travesías de búsqueda personal se canalizan a través de un deseo de encontrar un nuevo hogar donde sea posible renacer socialmente. Lo que cada una de estas películas ilustra es, así, una trayectoria de deriva comprendida entre dos momentos

6 Es ciertamente esto lo que ha conducido a Catalina Donoso a hablar, al referirse al motivo de la pasarela, de una "detención en movimiento", característica de cierto cine chileno reciente. 
decisivos: el abandono del hogar habitual, que nos es mostrado al comienzo de cada relato mediante secuencias de alto valor simbólico, y el hallazgo - real o figurado- de una nueva morada que permitirá sobrellevar de mejor manera la pérdida del lugar de origen, su deserción.

El árbol magnético es quizás la cinta que lleva más lejos esta dinámica, al menos en los planos discursivo y práctico. Ahora bien, si en De jueves a domingo - lo hemos ya sugerido un poco más arriba- el origen del conflicto que lleva al abandono del hogar es la discordia conyugal, en El árbol magnético las razones parecen ser exclusivamente financieras, lo que excluye cualquier otro tipo de consideraciones. La sensación de deriva de Marianela es, en consecuencia, más concreta y reflexiva que las de Amalia o Lucía, pues si el conflicto familiar abriga, en el caso de las dos últimas, la posibilidad de una reconciliación futura, los contratiempos económicos parecen no dejar, por el contrario, ningún espacio a la reconsideración. Así, hacia la mitad del filme, durante una conversación con sus primos, Marianela afirmará, por ejemplo: "Yo no sé dónde voy a ir cuando vendan esta casa”.

En Raíz, la elección del nuevo hogar está en cambio directamente relacionada con el restablecimiento de un vínculo filial perdido: Amalia se reconcilia con su madre, luego de años de separación. No es casual, en ese sentido, que la cinta termine con la promesa de Amalia de "echar raíces" nuevamente en su ciudad natal. Esta promesa, proferida ante el pequeño Cristóbal durante la última secuencia del filme ("Me voy a quedar... me voy a quedar aquí"), posee además un carácter doble. Por un lado, manifiesta su rechazo de la vida citadina, cuya naturaleza opresiva los planos de apertura nos mostraban ya sin equívoco. Por el otro, señala una suerte de duplicación de las relaciones familiares que representa la cinta: y es que quedarse, para Amalia, no significa solamente volver a ser hija, sino también, aunque de modo más sutil e indirecto, ser madre.

\section{Espejos y superficies especulares: mirar al "otro" que hay en sí}

El motivo del espejo participa de una necesidad de visibilidad y de autocontemplación que parece tener su origen en la brevedad del viaje emprendido. Es en efecto esa misma limitación temporal la que otorga a los personajes una oportunidad para observarse intensamente, sin ser molestados por otros estímulos exteriores, según una lógica de inmersión en la que la dilatación cronológica es inversamente proporcional a la profundidad del acto de autoauscultación.

A través del espejo, los personajes pueden contemplarse en su estado actual, constatar los cambios pasados y anticipar los futuros. Las superficies especulares son así, en el contexto de las cintas estudiadas, espacios en los que una nueva manera de mirarse a sí mismo puede manifestarse. En términos pictóricos, el espacio del espejo sirve para marcar además un punto de convergencia entre las miradas de los personajes y la de los espectadores, cuyos ejes de fuga coinciden, creando la sensación de 
una focalización altamente subjetiva o, al menos, íntima. Al situar la cámara detrás de un cuerpo que se observa sin por ello dejar de evidenciar la presencia del sujeto observador, los cineastas ilustran, por intermedio de la imagen - aunque de manera bastante literal - , el proceso de desdoblamiento que sacude a las protagonistas; su enfrentamiento con ese "otro" que poco a poco descubrirán en ellas mismas.

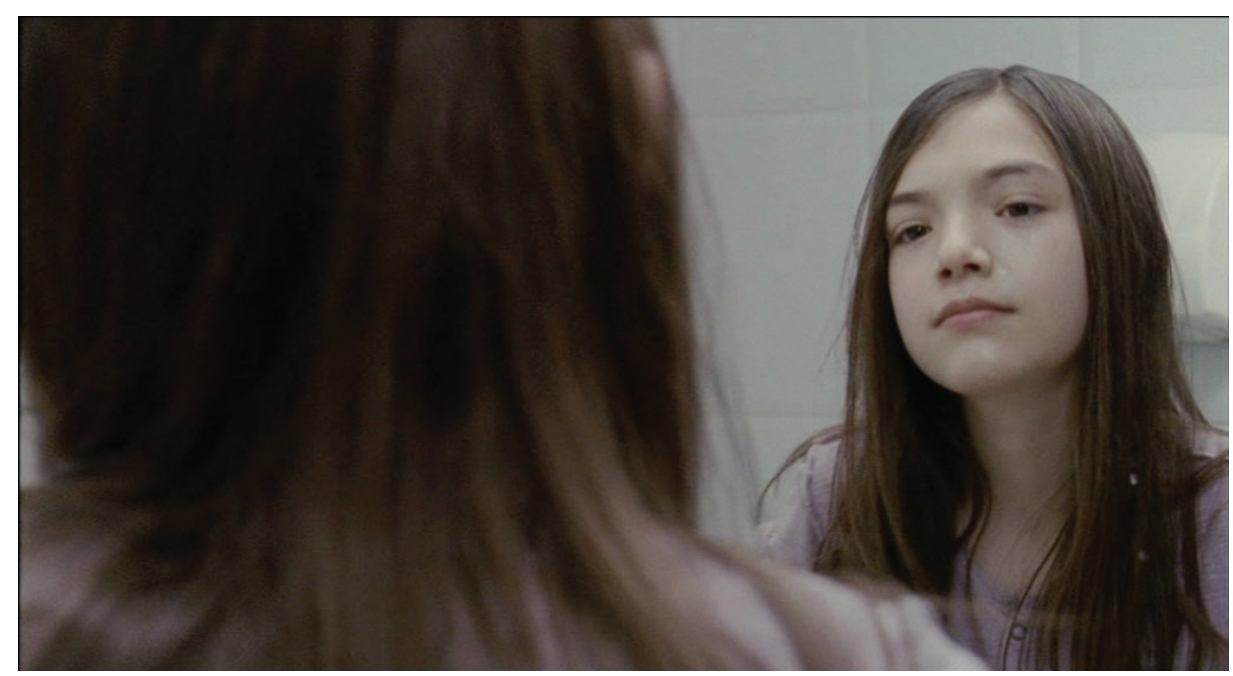

Lucía en De jueves a domingo.

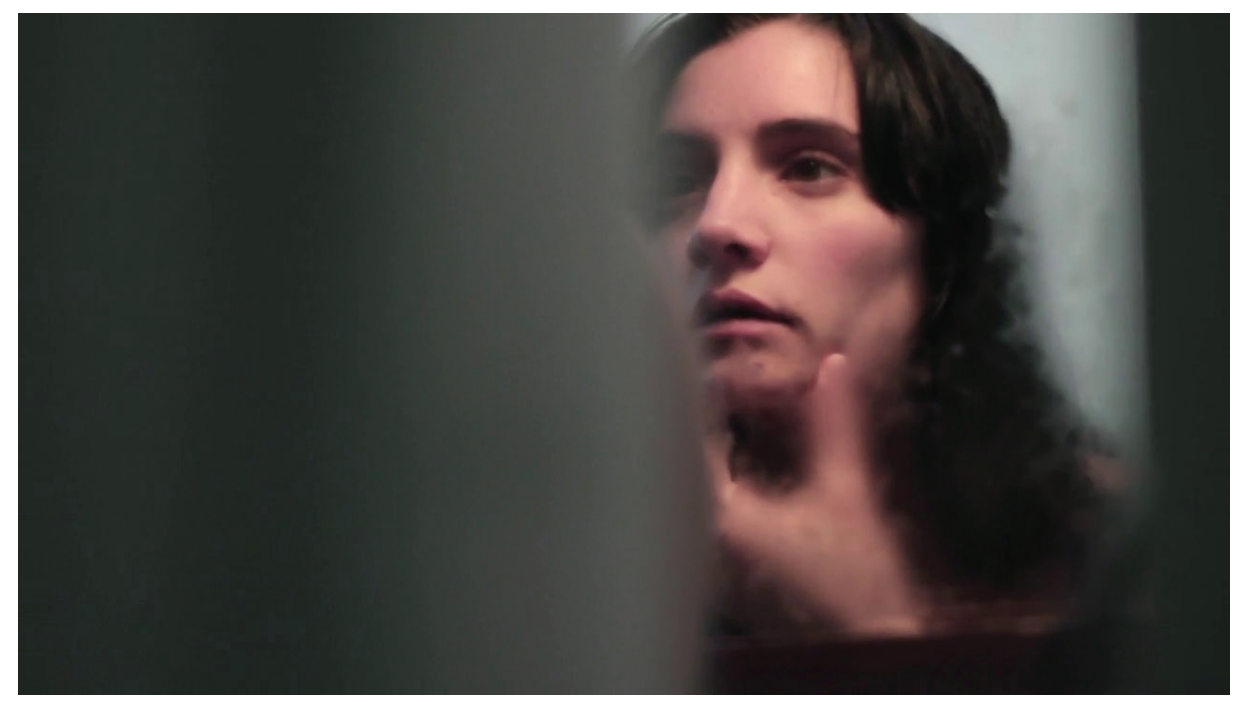

Amalia en Raíz. 


\section{Ventanas y miradores: la mirada proyectada hacia el exterior}

Si el espejo constituye un espacio de convergencia de miradas que se proyectan hacia el interior, la ventana, motivo no menos recurrente, señalará por otro lado el gesto contrario: la proyección de la mirada del personaje hacia el mundo exterior, hacia el fuera-de-campo, y su colisión con el eje de la mirada espectatorial, que la individualiza.

Como umbral, la ventana aparece pues en su dimensión liminar de frontera que demarca, encuadrándolo, el espacio de un "yo" inmóvil y contemplativo - el de las protagonistas - , y lo separa, sin por ello alienarlo, del universo de los acontecimientos, este último de naturaleza móvil. Gérard Wajcman escribe a este propósito: "la ventana que nos abre al mundo, delimita nuestro propio mundo, forma el límite del espacio que habitamos, de nuestro lugar. Es un borde que a la vez separa y une [traducido por el autor]".

Concretamente, el caso más ejemplar del modo de ordenamiento espacial al que nos referimos es De jueves a domingo, donde el lugar de la contemplación - el automóvil- adquiere una forma definida y reconocible. El árbol magnético y Raíz presentan, sin embargo, figuraciones también bastante concretas del motivo de la ventana. El segundo plano de Raíz, por ejemplo, nos muestra a Amalia de espalda, con su celular en la mano, frente a una gran ventana que se abre sobre Santiago. Un poco sombría y grisácea, la imagen parece querer señalar, por el ángulo de la toma (en un casi imperceptible contrapicado), el carácter angustiante y contrito de la vida citadina de la protagonista, quien estudia — un breve diálogo nos lo anuncia - la posibilidad de partir. El plano siguiente confirmará, por lo demás, estas impresiones: Amalia, ahora de perfil, mira por la ventana, llevando las manos a los labios, en un gesto de duda que prefigura su partida inminente.

Durante una de las secuencias iniciales de El árbol magnético, veremos por otro lado a Marianela, con un rostro entre distraído y soñador, mirar por un ventanal de su casa de vacaciones. El desarrollo de la intriga nos enseñará, algunos minutos más tarde, que, anticipando la venida de su primo, Marianela buscaba sorprenderlo, observarlo atravesar silenciosamente el jardín, ser en fin la primera en verlo llegar.

Resulta claro que en los dos ejemplos citados la ventana circunscribe, temporal y espacialmente, el momento, el lugar de una meditación, de un examen, de un sopesamiento acaso análogos a los que tenían lugar frente al espejo. Un aspecto no menor, sin embargo, diferencia en la práctica ambos motivos. Si el espejo privilegiaba, sobre todo, una mirada introspectiva que buscaba fijar una imagen presente del cuerpo de los protagonistas (¿cuánto se ha envejecido?, ¿cuánto se ha cambiado?), la ventana parece apuntar, al contrario, a la relación del sujeto con el mundo exterior, con los demás, en una dinámica temporal que será, siempre, doble. Y es que el potencial evocador de la ventana permite una proyección tanto hacia el pasado como hacia el futuro: Amalia, por ejemplo, vacila, dubitativa, pues el viaje que se apresta a emprender es, en el fondo — de ahí toda la complejidad del asunto-, un 
retorno al hogar de su infancia, un inevitable enfrentamiento con la figura de su madre. Marianela, por su parte, parece evocar en su imaginación el recuerdo de un tiempo también pretérito, un retorno, para ella y su primo español, a la infancia de un amor no resuelto.

\section{El entorno natural: tacto y contemplación}

El espejo y la ventana, en su calidad de cuadros, permiten aislar e individualizar pictóricamente los cuerpos de los personajes principales, explicitando la focalización de cada relato. Lo mismo ocurre, en un sentido más amplio, con los paisajes naturales que las protagonistas recorren y contemplan a lo largo de las tres cintas.

En el plano de la intriga, estas vistas - ya lo hemos sugerido un poco más arriba a propósito de Raíz - interrumpen de cierto modo el curso del relato, suspendiéndolo, dejándolo momentáneamente de lado en un devenir de temps morts, para solicitar, a personajes y espectadores, un tipo de mirada que se aleja en parte del flujo narrativo y que requiere, por eso mismo, un esfuerzo de contemplación más minucioso, más atento al detalle.

A través de un procedimiento de individuación contemplativa, lo que estas secuencias revindican en el fondo es la posibilidad de establecer un vínculo metonímico con el mundo natural, que aparecerá de ahora en adelante como un reflejo más o menos transparente - ya sea por contraste o por asimilación-de los estados anímicos o sentimentales de los protagonistas. Dos tipos de representaciones pictóricas vendrán a concretizar esta afinidad entre la interioridad psicológica de los personajes y el recogimiento propio a cada paisaje. No serán infrecuentes, por un lado, los planos generales o panorámicos en los que, perdidos en la distancia, los personajes recorren o contemplan en condiciones ideales (carreteras despobladas, solitarias, senderos vírgenes) paisajes cuya monumentalidad termina por absorberlos, reduciéndolos al estatuto de simples objetos decorativos. Por otro lado, una serie no menor de planos cerrados, de corta distancia, captura de manera fragmentaria las experiencias táctiles de las protagonistas, su contacto directo con la materia. Estas pueden, en efecto, tocar, experimentar y sentir con sus propias manos los detalles, las superficies y los atributos sensibles de los objetos que llaman su atención, trátese de árboles, de piedras o, simplemente — como lo veremos más adelante-, de corrientes de agua.

A estas dos modalidades de vecindad metonímica (los personajes se pierden en el paisaje sin experimentarlo o lo experimentan sin perderse en él) invitan a comprender el vínculo con la naturaleza como una de las claves de cada intriga y permiten relativizar, en palabras de Depetris, "el hermetismo de la intimidad, transformando lo exterior/interior en un espacio poroso, de flujos y contaminaciones” (43). Así, para Marianela, en El árbol magnético, la figura del árbol funcionará como un eco de sus propias pasiones amorosas y filiales. Para Amalia, en Raíz, en cambio, la naturaleza 
será la cifra de un cierto sentimiento de pertenencia a la tierra natal, de un deseo de retorno al origen. Finalmente, para Lucía, la protagonista de De jueves a domingo, las vistas naturales no serán más que una manifestación traslúcida del estado de deriva (entre padre y madre, entre infancia y adolescencia, entre movilidad e inmovilidad) en el que se encuentra.

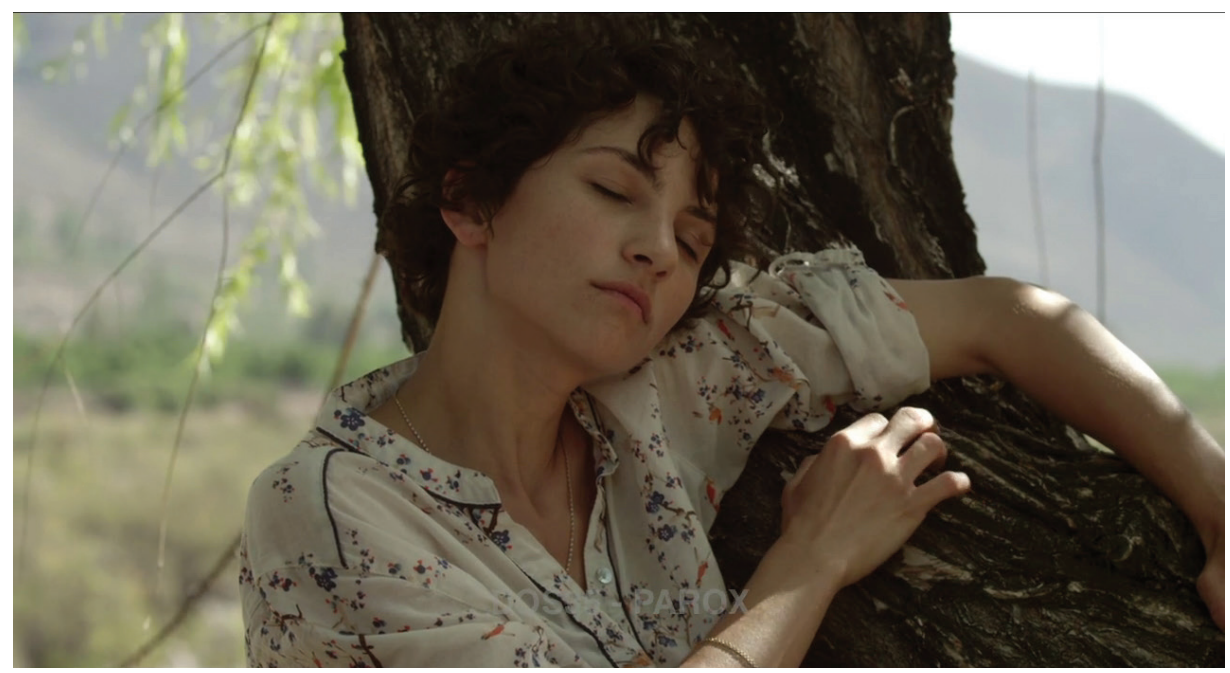

Marianela en El árbol magnético.

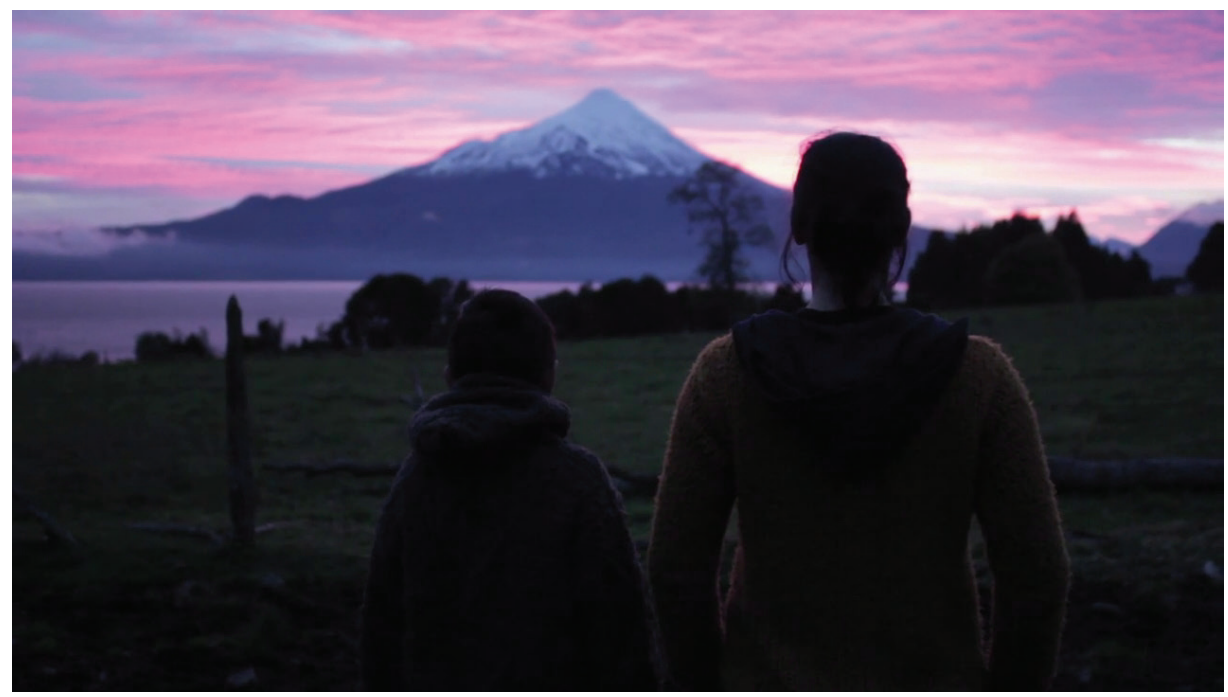

Amalia y Cristóbal en Raíz. 


\section{La ablución: paso y purificación}

La teoría del turismo, en sus elucidaciones, no deja lugar a dudas: la revalorización del mundo rural y de las prácticas viajeras de contracorriente puede transformarse fácilmente en un ejercicio de "fetichización" o de mistificación de la alteridad campestre. ¿Qué posición adoptan los filmes estudiados en esta encrucijada?

A primera vista, nada impide considerar que Marianela, Amalia y Lucía contribuyen en efecto a "la construcción del imaginario citadino en lo que concierne a la percepción del medio rural [traducido por el autor]" (Bessière 82). Uno de los principales indicios de esta interpretación es la convicción — citadina por antonomasia- de una posibilidad de reconciliación pacífica entre el sujeto y su entorno natural. El motivo del retorno a la naturaleza - en el que Amirou ve por lo demás un irreprimible eco aristocrático (206) - reposa, tanto en la literatura como en las prácticas de marketing turístico, sobre algunas variaciones simbólicas invariables. Una de ellas es la idea de lo rural como medio "purificador y terapéutico" (Bessière 82); en fin, como un "antídoto contra la ciudad y sus males" (83). Aunque estas dinámicas no están ausentes de los filmes estudiados, un análisis más minucioso nos indica que el panorama reviste una mayor complejidad.

En De jueves a domingo y El árbol magnético, esta suerte de ceremonia de purificación a través de la inmersión en el agua está desprovista de toda densidad dramática o de toda resonancia religiosa; su naturaleza, al contrario, es más bien lúdica, experimental. Marianela, por ejemplo, se introduce en una pequeña lagunilla para reestablecer, a través de un juego infantil, contacto con su primo venido del extranjero; Lucía, por su parte, se deja llevar por la corriente de un riachuelo para evadirse de un conflicto cuyas implicaciones presiente silenciosamente sin llegar a comprenderlas del todo.

"Nos sumergimos en el agua", escribe Gastón Bachelard, "para renacer renovados" (Agua 220). Pero, añade inmediatamente, "[s]i se participa de veras, por la imaginación material, en la sustancia del agua, se proyecta [énfasis original] una mirada fresca" (221). La constatación, en el caso de estas obras, no podría ser más acertada. Y es que el baño no solo purifica, limpia o regenera. En un sentido más profundo, la inmersión en el agua permite también a los personajes acceder a un estado, no necesariamente más feliz, de mayor madurez, de mayor consciencia con respecto al mundo; la inmersión propicia, en fin, en los personajes, la aparición de una nueva visión de los conflictos emocionales que los rodean: Marianela descubre la imposibilidad de revivir el amor de su infancia, Lucía se enfrenta a la certeza de un conflicto parental irresoluble, Amalia comprende la inevitabilidad del retorno a la tierra natal. ${ }^{7}$ En este sentido, el motivo en cuestión funciona más de manera indicial que metafórica, pues señala la inminencia

7 Deborah Martin ha escrito ya in extenso sobre la preminencia de los espacios líquidos y acuosos en el marco del cine argentino contemporáneo, que ella lee como un tropo háptico "empleado frecuentemente en la representación de deseos marginales o no-normativos que pueden situarse "más allá de la representación" (255). 
de un cambio, su estado de proceso todavía-en-curso, entre ser y devenir, y no el momento de su efectuación definitiva, características que podrían asociarlo acaso —en el marco de una posible lectura de género, aunque siempre con prudencia- a la noción de aquella chôra $(x \hat{\omega} \rho \alpha)$ matricial y preconceptual —informe e informante, ni sensible ni inteligible, a la vez pasiva y activa, condición en fin de un sujeto "en proceso" - que, desde el Timeo, y pasando por Kristeva, Derrida, Irigaray y otros tantos exégetas, propone, a la manera del cronotopo, una unión radical de tiempo y espacio (Sodërback 96), en lo que Deleuze ha calificado por su parte como un spatium intensivo (Burchill 90).

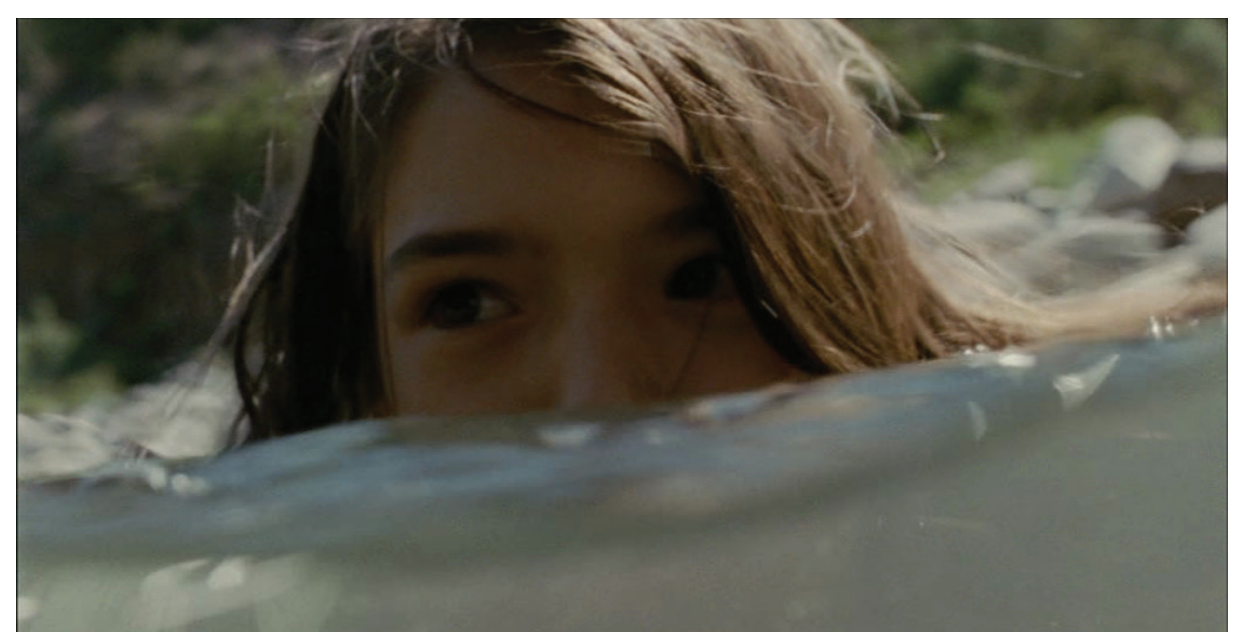

Lucía en De jueves a domingo.

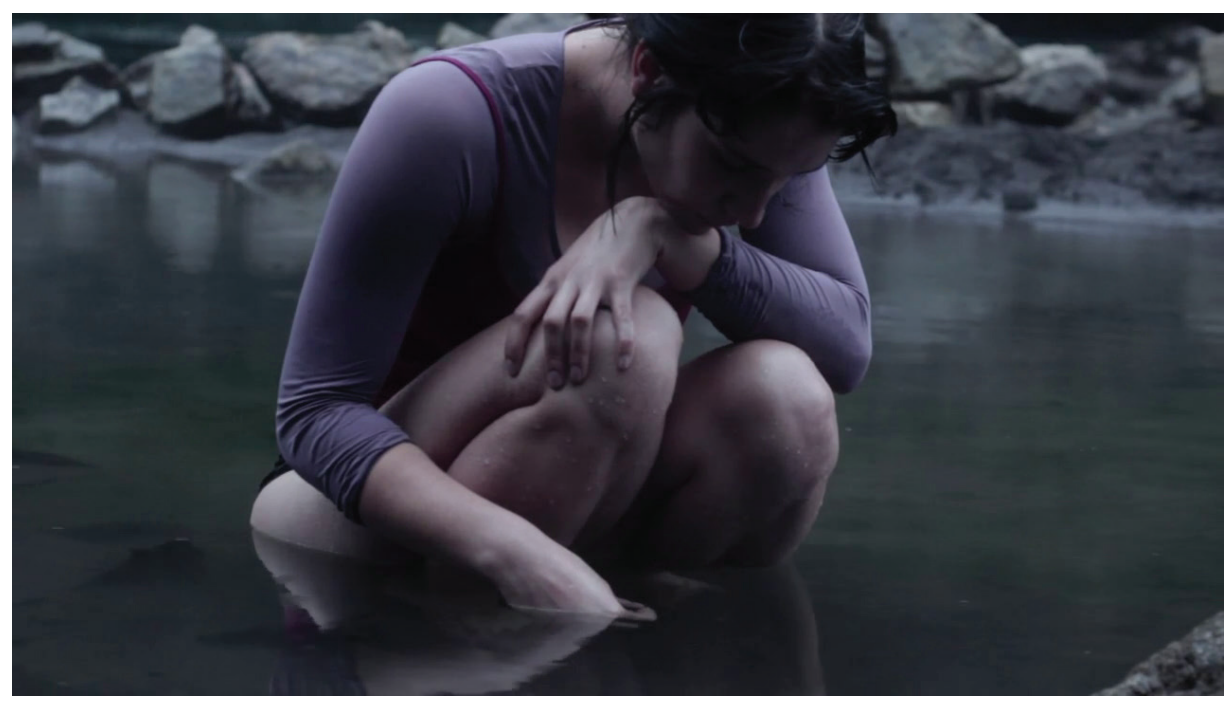

Amalia en Raíz. 


\section{Conclusiones}

Decíamos más arriba que los desplazamientos de cada uno de los relatos estudiados son ejercicios de movilidad voluntarios, no forzados, que responden al deseo difuso - y resumido ejemplarmente por el adagio de Montaigne - de cambiar momentáneamente de cuadro de vida; itinerarios que Depetris caracterizara recientemente como "dulces y melancólicos", en los que se evidencia "la persistencia de ciertas figuras de la dislocación" (Depetris 19) y de espacios abiertos cada vez "más vinculados a la esfera de la intimidad" (43). En ese sentido, se aproximan a ciertas trayectorias puestas en escena, de forma paralela, en la novela chilena reciente, especialmente en las obras de Alejandro Zambra y Diego Zúñiga. A propósito del trabajo de estos dos escritores, Lorena Amaro Castro, académica chilena, reconoce: "Habría que decir, pues, que la cuestión radica hoy en salir de casa" (126). Después de lo cual, en modo prospectivo, y en absoluta armonía con nuestras inquisiciones, se pregunta: "Pero ¿a dónde?” (126).

Podemos notar, bajo esta misma lógica, que las trayectorias trazadas por los respectivos personajes sobre los territorios recorridos no poseen mayor complejidad. Su elucidación cartográfica, por lo demás, no constituye en lo absoluto un punto decisivo de la comprensión de la trama de cada relato. En efecto, las cintas parecen reposar menos en el reconocimiento exacto (o etiquetaje) de las imágenes naturales capturadas por la cámara que en la manera en que este mismo paisaje permite a los personajes, en razón de atributos genéricos — monumentalidad, belleza, calma-, desarrollar un modo particular de introspección, de búsqueda de sí mismos a través de un ejercicio continuo de errancia. En términos más concretos, resultará indiferente que Amalia, en Raíz, viaje al encuentro de su madre en el sur de Chile, o que Marianela, en El árbol magnético, recorra en cambio los campos del Valle Central, pues el cambio operado en ambas protagonistas hacia el final de cada obra no dependerá de las particularidades geosociales de los nuevos espacios recorridos. Las coordenadas geográficas de cada filme podrían incluso cambiar drásticamente, invertirse; el resultado de las intrigas sería, en cualquier caso, idéntico, gracias en parte a la "saturación" del cronotopo del camino y al peso indistinto de los momentos afectivos - hechos de pura intensidad- que este propicia.

Stricto sensu, nuestras protagonistas recorren, en términos de Deleuze y Guattari, un "espacio liso", "direccional, no dimensional o métrico" (487). En Mil mesetas, los filósofos precisan la noción: "El espacio liso", afirman, "está ocupado por acontecimientos [...], mucho más que por cosas formadas o percibidas. Es un espacio de afectos más que de propiedades." (487). Más abajo, añaden: "el espacio liso está ocupado por las intensidades, los vientos y los ruidos, las fuerzas y las cualidades táctiles y sonoras, como en el desierto, la estepa o los hielos" (487).

Carolina Urrutia apunta a un fenómeno similar al señalar que los filmes chilenos de los últimos años parecen centrarse más bien en el establecimiento de "nuevas jerarquías entre el protagonismo del sujeto y el protagonismo del espacio" (Un Cine 20), que en "la 
representación y el registro de los folclores” (36). Muy en la línea de nuestras propias conclusiones, la autora agrega, acercándose en parte al léxico de Deleuze, cuya filiación por lo demás reconoce: "son los centros de gravedad [...] los que se ven afectados y desplazados en el cine chileno de los últimos años. En ese deslizamiento se instalan las historias sin centro aparente, más fluidas y livianas" (34).

No es en lo absoluto sorprendente que Syed Manzurul Islam recurra a la misma metáfora de la gravedad para caracterizar a aquellos viajeros sedentarios, inmóviles, que, en las antípodas de las protagonistas de nuestras obras, cargan consigo un "territorio portable" que previene toda transformación, todo encuentro con el "otro". En efecto, para el académico bengalí, "[c] omo sujeto de representación, [el viajero sedentario] traza un mapa geográfico, en lugar de componer un mapa performativo de intensidades [...], con el objetivo de establecer puntos según las leyes de la gravedad" (59).

Es acaso esa misma indeterminación geográfica o, en palabras de Urrutia, esa misma pérdida de los centros de gravedad, la que justifica en último término la pertinencia de una lectura cronotópica, genérica o arquetípica de las obras analizadas, indiferente a la pregunta por "relación con nuestro imaginario del territorio nacional" (Urzúa 182) que parece preocupar a algunos comentaristas. Si, como afirman Deleuze y Guattari al referirse a los espacios lisos, "los puntos están subordinados al trayecto [...], el hábitat al recorrido, [...] el espacio interior al exterior” (487), resulta natural que los relatos cifren, en su condensación temporal y geográfica —se viaja poco, se viaja cerca, se viaja, al fin, "por intensidad”-, la clave de sus poéticas respectivas. Para Islam, sin ir más lejos, esa intensidad es el signo, en las modalidades viajeras lisas, de un paso, de un trayecto constante, sin cese y, al fin, de la posibilidad entrevista de una transformación, como lo evidencian indistintamente El árbol, Raíz y De jueves a domingo: "Es una línea de dirección que en último término nos lleva más allá del umbral, a la línea de vuelo, hacia un 'devenir-otro'. No tiene inicio ni final; solo la circulación en el medio, habitando la multiplicidad del 'entre-dos', entregado al acontecimiento, a la suerte, al encuentro" (60). Y a su vez, aquel "entredos", ilustrado aquí mediante cinco submotivos cronotópicos - la casa, el espejo, la ventana, el entorno natural y la ablución - no es por lo demás, como lo recuerda Selimović, otra cosa que la experiencia de "medianidad" (in-between-ness) necesaria al surgimiento de todo afecto (11).

Viajes en los que se camina, se conduce en rutas despobladas, se descubren senderos inexplorados, se experimentan nuevas sensaciones de intimidad con la naturaleza y se redescubren, por acopio, vínculos filiales que se creían rotos para siempre: es ese, en pocas palabras, el balance de las modalidades viajeras propuestas en los filmes que nos convocan. En ellos, el viaje es comprendido, efectivamente, no como una "fuga" o una "evasión", sino más bien como un derrotero en el que se habita transitoriamente en pos de un aprendizaje potencial; una ruta que conduce, en fin, hacia el restablecimiento posible, ya que no efectuado, de "una sociabilidad perdida" (Amirou 244). En ese sentido, su parentesco con los ritos de paso resulta evidente, 
hecho que viene a reforzarse si se considera los intervalos de edad (nuevas figuras de la medianidad) dentro de los que se mueven los protagonistas: paso, prematuro en el caso de Lucía, de la infancia a la adolescencia; tardío, para Marianela, entre la adolescencia y la adultez, y postergado, en el caso de Amalia, entre la pérdida y la recuperación de un vínculo filial. ${ }^{8}$

El cronotopo del camino, al impregnarse de la metáfora de un proceso en curso y al presentarse también en términos de una saturación, nos permite desembocar finalmente en una noción abordada de paso en las páginas anteriores y retomada en una de sus variaciones un poco más arriba: el medio, que entendíamos con Thomas como el lugar de un "entre-pertenencia de cuerpos y espacios" (30). Es a través de la elaboración de medios que el cine, al instalar justamente las condiciones de una atención saturada, logra dar a gestos lábiles y de costumbre dispensables la intensidad que la realidad cotidiana no sabría imprimirles. Y nos recuerda con ello que "la existencia del mundo diegético como algo distinto de una escenografía invisible no tiene necesariamente que ocurrir a la luz de las justificaciones dramáticas o sicológicas exigidas por la lógica de la intriga". El mundo representado puede, en efecto, volverse perceptible o cristalizarse también a través de imágenes - o más bien dentro de ellas-, en el marco de espacios-tiempos de duración variable (llámense cronotopos, momentos afectivos o medios) en los que, de pronto, y de manera relativamente independiente de toda carga narrativa, algo "marcadamente concentrado" (Selimović 14) se manifiesta y logra "hacer visibles fuerzas que [en principio] no lo son" (Deleuze, cit. en Selimović 14).

\section{Referencias}

Amaro Castro, Lorena. "Formas de salir de casa, o cómo escapar del Ogro: relatos de filiación en la literatura chilena reciente". Literatura y lingüística, n. ${ }^{\circ} 29,2014$, pp. 96-109.

Amirou, Rachid. Imaginaire touristique et sociabilités du voyage. París, Presses Universitaires de France, 1995.

Areco, Macarena, Marcial Huneeus, Jorge Manzi y Catalina Olea. Cartografía de la novela chilena reciente: Realismos, experimentalismos, hibridaciones y subgéneros. Santiago de Chile, Ceibo, 2015.

Bachelard, Gastón. Poética del espacio. Buenos Aires, Fondo de Cultura Económica, 2000.

--. El agua y los sueños. Ensayo sobre la imaginación de la materia. México D. F., Fondo de Cultura Económica, 2003.

8 Ahora bien, esta modalidad de representación de lo rural, cabe aclararlo, no obedece de ningún modo a una oposición maniquea entre "centro y periferia" en la que lo campestre representaría lo auténtico y los espacios urbanos lo abyecto. Lo rural, en estos filmes, aparece más bien - quisiéramos volver a repetirlo- como la concretización de una alteridad local, ni totalmente ajena ni completamente familiar. 
Bajtín, Mijail. Teoría y estética de la novela. Madrid, Taurus, 1989.

Barraza, Vania. El cine en Chile (2005-2015): políticas y poéticas del nuevo siglo. Santiago de Chile, Cuarto Propio, 2018.

Bessière, Jacinthe. "Valeurs rurales et imaginaire touristique". Le tourisme local. Ed. Rachid Amirou y Philippe Bachimon. París, L’Harmattan, 2000, pp. 71-92.

Burchill, Louise. "Re-situating the Feminine in Contemporary French Philosophy". Belief, Bodies, and Being: Feminist Reflections on Embodiment. Lanham, Rowman \& Littlefield Publishers, 2006, pp. 81-101.

Cavallo, Ascanio y Maza, Gonzalo. "Explicación de este libro”. El novísimo cine chileno. Santiago de Chile, Uqbar, 2010, 13-16.

Clifford, James. “Traveling cultures”. Cultural studies. Nueva York, Routledge, 1992, pp. 96-116.

Chamorro, Miguel. "El nuevo mensaje en el cine chileno: entrevista a tres cineastas nacionales". Revista Faro, n. ${ }^{\circ}$ 13, 2013, pp. 217-226.

Cohen, Erik. "A phenomenology of tourist experiences". Sociology, n. ${ }^{\circ} 13,1979$, pp. 179-201.

Corro, Pablo. "Las poéticas débiles". Retóricas del cine chileno. Ensayos con el realismo. Santiago de Chile, Cuarto Propio, 2012, pp. 217-226.

Deleuze, Gilles y Guattari, Félix. Mil mesetas. Capitalismo y esquizofrenia. Valencia, Pre-Textos, 2004.

Díaz-Zambrana, Rosana. "Los fracasos del viaje en el cine chileno contemporáneo". In Between: Cultures and Languages in Transition. Florida, BrownWalker Press, 2019, pp. 57-67.

Depetris, Irene. Geografías afectivas, Desplazamientos, prácticas espaciales y formas de estar juntos en el cine de Argentina, Chile y Brasil (2002-2017). Pittsburgh, Latin America Research Commons, 2019.

Donoso Pinto, Catalina. Detención en movimiento. El no-adulto como fuerza rebelde en dos filmes chilenos contemporáneos. Cinémas d'Amérique Latine, n. ${ }^{\circ}$ 23, 2015, 135-143,

Estévez, Antonella. "Dolores políticos: reacciones cinematográficas. Resistencias melancólicas en el cine chileno contemporáneo". Aisthesis, n. 47, 2010, pp. 15-32.

- - Una gramática de la melancolía cinematográfica. La modernidad y el no duelo en cierto cine chileno contemporáneo. Santiago de Chile, Radio Universidad de Chile, 2018.

Fussell, Paul. Abroad: British Literary Traveling between the Wars. Oxford, Oxford University Press, 1982.

Kemp, Leah. "La amoralidad del individualismo en Tony Manero y sus antecesores". El estado de las cosas. Cine latinoamericano en el nuevo milenio. Ed. Gabriela Copertari y Carolina Sitnisky. Frankfurt am Main, Vervuert, 2015, pp. 205-228.

Larraín, Carolina. "Nuevas tendencias del cine chileno tras la llegada del cine digital". Aisthesis, n. ${ }^{47}$, 2010, pp. 156-171. 
Lie, Nadia. The Latin American (Counter-) Road Movie and Ambivalent Modernity. Londres, Palgrave Macmillan, 2017

López Barraza, Andrea. "Nuevo Cine Chileno: 2005 - 2010”. Tesis para optar al grado de Magíster en Artes, Universidad de Chile, 2011. http://repositorio.uchile.cl/ handle/2250/113844

Manzurul Islam, Syed. The Ethics of Travel. From Marco Polo to Kafka. Manchester, Manchester University Press, 1996.

Martin, Deborah. "Planeta Cinénaga: Lucrecia Martel and Contemporary Argentine Women's Filmmaking”. Latin American Women Filmmakers: Production, Politics, Poetics. Londres, Tauris, 2017, pp. 241-262.

Montaigne, Michel de. De la vanidad. Buenos Aires, Libros del Zorzal, 2006.

Navarro-Daniels, Vilma. "De jueves a domingo, de Dominga Sotomayor Castillo, o el 'viaje a ninguna parte' de un país llamado Chile". Letras Hispanas, n. ${ }^{\circ}$ 12, 2016, pp. 186-197.

Parra, José. "El cine en Chile (2005 - 2015): Políticas y poéticas del nuevo siglo". laFuga, n. ${ }^{\circ}$ 22. http://2016.lafuga.cl/el-cine-en-chile-2005-2015-politicas-ypoeticas-del-nuevo-siglo/956

Pino-Ojeda, Walescka. “'Be a Man!': Masculinities and Class Privileges in Post-Coup Chilean Cinema”. Screening Minors in Latin American Cinema. Eds. Carolina Rocha y Georgia Seminet. Plymouth, Lexington Books, 2014, pp. 87-104.

Pinto, Iván. "Rupturas, procesos y desvíos. Coyunturas críticas y académicas en la recepción del Novísimo cine chileno”. Revista F@ro, vol. 2, n. 22, 2015, pp. 110-132.

- - "Materialismos. Apuntes sobre los trabajos de José Luis Torres Leiva y José Luis Sepúlveda”. En Travesías por el cine chileno y latinoamericano. Ed. Mónica Villarroel. Santiago, LOM, 2014, pp. 135-144.

Pinto, Iván, Sebastián González y Vanja Munjin. “Operación termita: por una segunda línea en el cine chileno”. Cuadernos.info, n. ${ }^{\circ}$ 43, 2018, pp. 71-83.

Póo, Ximena, Claudio Salinas y Hans Stange. "Políticas de la subjetividad en el novísimo cine chileno". Comunicación y medios, n. ${ }^{\circ}$ 26, 2012, pp. 5-11.

Randall, Rachel. Children on the Threshold in Contemporary Latin American Cinema: Nature, Gender and Agency. Lanham, Lexington Books, 2017.

Saavedra, Carlos. Intimidades desencantadas. La poética cinematográfica del dos mil. Santiago de Chile, Cuarto Propio, 2013.

Salinas, Claudio e Stange, Hans. "Títeres sin hilos: Sobre el discurso político en el novísimo cine chileno". Aisthesis, n. ${ }^{\circ}$ 57, 2015, pp. 219-233.

Selimović, Inela. Affective Moments in the Films of Martel, Carri and Puenzo. Londres, Palgrave Macmillan, 2018.

Sodërback, Fanny. “Julia Kristeva face aux féministes américaines”. L’infini, n. ${ }^{\circ} 111$, 2010, pp. 86-107.

Thomas, Benjamin. Faire corps avec le monde: de l'espace cinématographique comme milieu. Estrasburgo, Circé, 2019. 
Urrutia, Carolina. "Hacia una política en tránsito: ficción en el cine chileno (2008-2010)". Aisthesis, n. ${ }^{\circ}$ 47, 2010, pp. 33-44.

-—. Un cine centrífugo: ficciones chilenas 2005-2010. Santiago, Cuarto Propio, 2013. Urzúa, Macarena. "Desde mi ventana, el desierto en los ojos de la infancia: De jueves a Domingo de Dominga Sotomayor". Taller de Letras, n. ${ }^{\circ}$ 55, 2014, pp. 169-184.

Valenzuela Prado, Luis. "En tránsito. Desplazamientos nimios en el cine latinoamericano (2000-2010)”. Aithesis, n. ${ }^{\circ}$ 48, 2010, pp. 141-154.

Wajcman, Gérard. Fenêtre: chroniques du regard et de l'intime. Lagrasse, Verdier, 2004.

Enviado: 12 de noviembre de 2018 Aceptado: 23 de enero de 2020 